\title{
25. BOREHOLE TELEVIEWER DATA ANALYSIS OF HOLE 504B FROM LEGS 137 AND 140'1
}

\author{
Anton Krammer, ${ }^{2}$ Philippe Pezard,${ }^{3}$ Peter K.H. Harvey, ${ }^{4}$ and Karl Fuchs ${ }^{2}$
}

\begin{abstract}
Hole 504B, about $200 \mathrm{~km}$ south of the Costa Rica Rift in the eastern equatorial Pacific, has been drilled over a succession of Deep Sea Drilling Project (DSDP) and Ocean Drilling Program (ODP) legs to a total depth of 2000.4 meters below seafloor (mbsf). Borehole televiewer (BHTV) measurements were recorded over the intervals 275-497 mbsf on Leg 137, and 1497$1715 \mathrm{mbsf}$ and 1868-1990 mbsf on Leg 140. Detailed investigation of the BHTV data revealed stress-induced wellbore breakouts in all depth intervals with variable occurrence. The statistical analysis of the wellbore breakouts shows that the orientation of the maximum horizontal stress $\left(S_{\text {mir }}\right.$ ) varies from N53 ${ }^{\circ} \mathrm{E} \pm 28^{\circ}$ in the interval $410-490 \mathrm{mbsf}$, to $\mathrm{N} 21^{\circ} \mathrm{E} \pm 35^{\circ}$ in the interval $1497-1715 \mathrm{mbsf}$, and $\mathrm{N} 82^{\circ} \mathrm{E} \pm 38^{\circ}$ in the interval $1868-1990 \mathrm{mbsf}$. Whereas the intermediate depth interval shows a mean azimuth that is consistent with previous observations from borehole breakout analysis between 700 and 1500 mbsf, the upperand lowermost breakout intervals are rotated clockwise by $22^{\circ}$ and $61^{\circ}$, respectively. As none of the observed intersecting structures correlates with the observed rotation of $S_{H m a x}$, it is assumed that the rotation is affected by non-intersecting structures or structures beyond the wellbore head. The onset of the breakout interval from 410 to $490 \mathrm{mbsf}$ correlates well with the Layer $2 \mathrm{~A} / 2 \mathrm{~B}$ boundary and corresponds to a seismic anisotropy observed in the upper $500 \mathrm{~m}$ of the crust. For breakouts to occur in shallow depths, high $S_{\text {Himur }} / S_{\text {hmin }}$ ratios are required or rock strengths must locally vary (to values $<100 \mathrm{MPa}$ ) to allow the initiation of breakouts. Analytical results also propose a drastic reduction of pore pressure $(20 \%)$ for breakout initiation, which is, however, far beyond present-day observations. The breakouts below $1497 \mathrm{mbsf}$ occur within the sheeted dikes and close to the sheeted dike/gabbro transition zone (1868-1990 mbsf). The observation of breakouts below $1497 \mathrm{mbsf}$ and the lack of vertical fractures in this depth allow us to estimate $131 \mathrm{MPa}$ for $S_{H_{\max }}$ and $96 \mathrm{MPa}$ for $S_{\text {hmin }}$, which agree with stress estimates deduced with Byerlee's law for a TF/SS regime.
\end{abstract}

\section{INTRODUCTION}

Hole 504B is located about $200 \mathrm{~km}$ south of the Costa Rica Rift (Fig. 1) in the eastern equatorial Pacific. The drilling and logging history of Hole 504B started as early as the Deep Sea Drilling Project (DSDP) Legs 69 and 70 (Cann, Langseth, et al., 1983). It was continued on Leg 83 (Anderson, Honnorez, Becker, et al., 1985), Leg 92 (Leinen, Rea, et al., 1986), and Ocean Drilling Program (ODP) Leg 111 (Becker, Sakai, et al., 1988), accompanied by a series of downhole logging programs. Legs 137 (Becker, Foss, et. al., 1992) and 140 (Dick, Erzinger, Stokking, et al., 1992) successfully deepened Hole 504B by $59 \mathrm{~m}$ (Leg 137) and $379 \mathrm{~m}$ (Leg 140), to a final depth of 2000.4 mbsf. This makes it the deepest hole drilled into oceanic crust. At the end of Leg 140. Hole 504B penetrated $274.5 \mathrm{~m}$ of sediments, $571.5 \mathrm{~m}$ of pillow lavas, a $209-\mathrm{m}$-thick transition zone, and $945.4 \mathrm{~m}$ of sheeted dikes.

As part of an extensive logging program during Legs 137 and 140 , borehole televiewer (BHTV) measurements were conducted with a slimhole BHTV in the upper (pillow lava) section (Becker, Foss, et. al., 1992) and with a high-temperature BHTV (HTT BHTV) in the lower, newly drilled sections of the hole (Dick, Erzinger, Stokking, et al., 1992). For the present study, all BHTV data obtained on Legs

'Erzinger, J., Becker, K., Dick, H.J.B., and Stokking, L.B. (Eds.), 1995. Proc. ODP. Sci. Results, 137/140: College Station. TX (Ocean Drilling Program).

Universität Karlsruhe, Geophysikalisches Institut, Hertzstr. 16, D-76187 Karlsruhe, Federal Republic of Germany.

'Institut Méditerranéan de Téchnologie, Téchnopole de Châteaux-Gombert, 13451 Marseille Cedex 13, France,

${ }^{4}$ Borehole Research, Department of Geology, University of Leicester, Leicester, LE1 7RH, United Kingdom.
137 and 140 were analyzed for borehole breakouts and vertical fractures and compared with previous results from BHTV measurements at intermediate depth sections of this hole (Newmark et al., 1985; Morin et al., 1989) under consideration of ancillary information about the nearby tectonic setting. In addition, disturbed (logging after the end of drilling and circulation; e.g., Dick, Erzinger, Stokking, et al., 1992) and undisturbed (logging after reentry, Gable et al., 1989; Becker, Foss, et. al., 1992) temperature profiles through the complete borehole were used to estimate the temperature effect on borehole breakout and vertical fracture initiation.

\section{DESCRIPTION OF THE BHTV}

The digital BHTV emits acoustic pulses, records amplitudes and travel times of the pulses reflected from the borehole wall, and provides a high-resolution image of the borehole wall. The reflected impulses contain information about the geometry of the borehole (travel time of the pulse), and the state, smoothness, and reflectivity of the borehole wall (amplitude of the pulse).

The slimhole BHTV (Leg 137) and the HTT BHTV (Leg 140) differ only in their outer diameter due to a heat sink (dewar) in the HTT BHTV that allows logging at temperatures up to at least $230^{\circ} \mathrm{C}$. A detailed technical description of the digital BHTV and the set-up of the BHTV recording system used by ODP is given by Krammer et al. (1994). During uphole logging on Leg 137 and Leg 140 the heave compensator was run to compensate for the ship vertical heave movement. To avoid jerking of the tool (sudden upward moves of the logging tool) which often occurs at the standard logging speed of 100 mph during uphole logging, a higher vertical logging speed was chosen (Table 1). A detailed listing of the vertical logging velocities and achieved vertical resolutions is given in Table 1. 


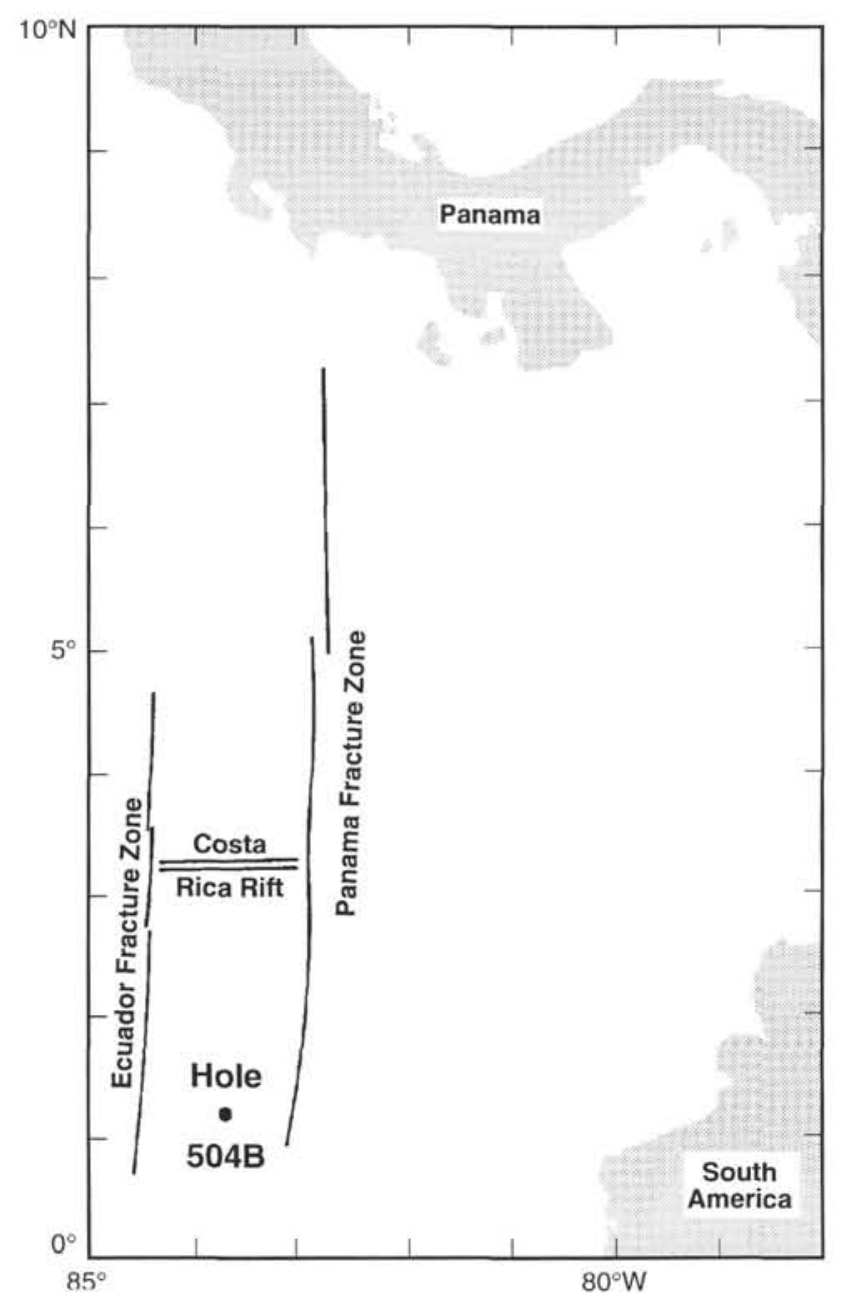

Figure 1. Location map of Hole 504B in the eastern equatorial Pacific.

Stress-induced borehole elongations (breakouts) and drilling- or thermal-induced vertical fractures can be detected in the digital images recorded by the BHTV. Breakouts appear in the BHTV data as two approximately symmetrical azimuthal features in both the amplitude and in the traveltime data. Within a borehole breakout interval, the amplitude of the reflected signal decreases because of scattering of the signal at the rough borehole wall, and the traveltime increases owing to the elongation of the borehole (Fig. 2; e.g., Zemanek et al., 1970). Tensile fractures should appear as tight azimuthal features with low amplitudes approximately $180^{\circ}$ apart on the borehole wall (Zemanek et al., 1970; Hüsges and Müller, 1991; Tenzer et al., 1992; Apel et al., unpubl. data).

\section{METHODS OF STRESS EVALUATION}

Stress-induced borehole deformations (borehole breakouts or tensile fractures) are reliable indicators for the determination of the horizontal stress field (e.g., Bell and Gough, 1979; Zoback et al., 1985; Blümling, 1986; Moos and Zoback, 1990; Morin et al., 1990; Mastin et al., 1991). A first analytical solution for the variation of the stresses around a circular borehole in an elastic material was given by Kirsch in 1898. Assuming that in an elastic material under hydrostatic pressure conditions, and an anisotropic horizontal far-field stress field
Table 1. Depth intervals logged with the BHTV during Legs 137 and 140.

\begin{tabular}{ccccc}
\hline Leg & $\begin{array}{c}\text { Depth } \\
\text { (mbsf) }\end{array}$ & & $\begin{array}{c}\text { Vertical } \\
\text { logging } \\
\text { velocity } \\
(\mathrm{m} / \mathrm{h})\end{array}$ & $\begin{array}{c}\text { Vertical } \\
\text { resolution } \\
(\mathrm{mm} / \mathrm{rev})\end{array}$ \\
\hline 137 & $\begin{array}{l}\text { Casing } \\
(0-274.5)\end{array}$ & $(\uparrow)$ & $250-300$ & $\sim 14$ \\
137 & $274.5-497.0$ & $(\downarrow)$ & 900 & $\sim 42$ \\
137 & $393.0-497.0$ & $(\uparrow)$ & 300 & -14 \\
140 & $1497-1715$ & $(\uparrow)$ & 200,300 & $\sim 8, \sim 14$ \\
140 & $1868-1990$ & $(\uparrow)$ & 200 & $\sim 8$ \\
\hline
\end{tabular}

Note: The direction of the arrows indicates the logging direction $(\uparrow:$ uphole; $\downarrow$ : downhole),

( $S_{\text {Hmax }}$-maximum, $S_{\text {lamin }}$-minimum horizontal far-field stress), one of the principal stress axes is parallel to the wellbore axis, the stresses acting at the borehole wall $\left(\sigma_{\theta \theta}^{*}-\right.$ circumferential stress; $\sigma_{r r}^{*}$-radial stress $=$ normal stress; $\tau_{r \theta}, \tau_{z \theta}, \tau_{z r}-$ tangential shear stresses) can be described as follows (Jaeger and Cook, 1979):

$$
\begin{gathered}
\sigma_{\theta \theta}^{*}=\left(S_{H \max }+S_{h \min }\right)-2\left(S_{H \max }-S_{h \min }\right) \cos 2 \theta, \\
\sigma_{r \prime}^{*}=P_{f} \text { and } \\
\tau_{z n}, \tau_{z \theta}, \tau_{r \theta}=0,
\end{gathered}
$$

where

$S_{\text {Hmax }}=$ total maximum horizontal far-field stress,

$S_{\text {hmin }}=$ total minimum horizontal far-field stress,

$\theta=$ angle with respect to the direction of $S_{H \max }$, and

$P_{f}=$ fluid pressure in the borehole.

Various rock studies (e.g., Handin et al., 1963) have shown that the failure of rock is affected by the effective stress. Therefore, the total far-field stresses are reduced by the pore pressure $\left(P_{p}\right)$ in the rock. Breakouts are assumed to be caused by compressive shear failure in the direction of the least horizontal stress (e.g., Gough and Bell, 1981), if the difference between the radial stress (due to the borehole fluid head in the wellbore) and the circumferential stress at the borehole wall $\left(\sigma_{t} \theta\right)$ exceeds the compressive strength $(C)$ of the rock. Under the assumption that the wellbore fluid pressure equals the pore pressure in the rock formation and $C$ is a positive quantity, Equations $I$ and 2 change into:

$$
\begin{gathered}
\sigma_{\theta \theta}=\left(S_{H \max }+S_{\text {limin }}\right)-2\left(S_{H \text { max }}-S_{\text {lmin }}\right) \cos 2 \theta-2 P_{p} \geq C, \text { and }(1 \mathrm{~A}) \\
\sigma_{r r}=\Delta P=0
\end{gathered}
$$

where $\sigma_{\theta \theta}$ is now the effective stress and $\Delta P$ summarizes the difference between the fluid pressure in the borehole and the pore fluid pressure in the formation.

Similarly, if the tensile strength of the rock ( $T$, with $T$ being a positive number) is exceeded, tensile failure occurs. Hence, Equation 1 can be written as:

$$
\sigma_{\theta \theta}=\left(S_{H \max }+S_{\text {himin }}\right)-2\left(S_{H \max }-S_{\text {lumin }}\right) \cos 2 \theta-2 P_{p} \leq-T .
$$

A sketch of the variation of the circumferential stresses $\left(\sigma_{\theta \theta}\right)$ is shown in Figure 3. Here, a $S_{\text {Hmax }} / S_{\text {hmin }}$ ratio of 2.0 is assumed for the 


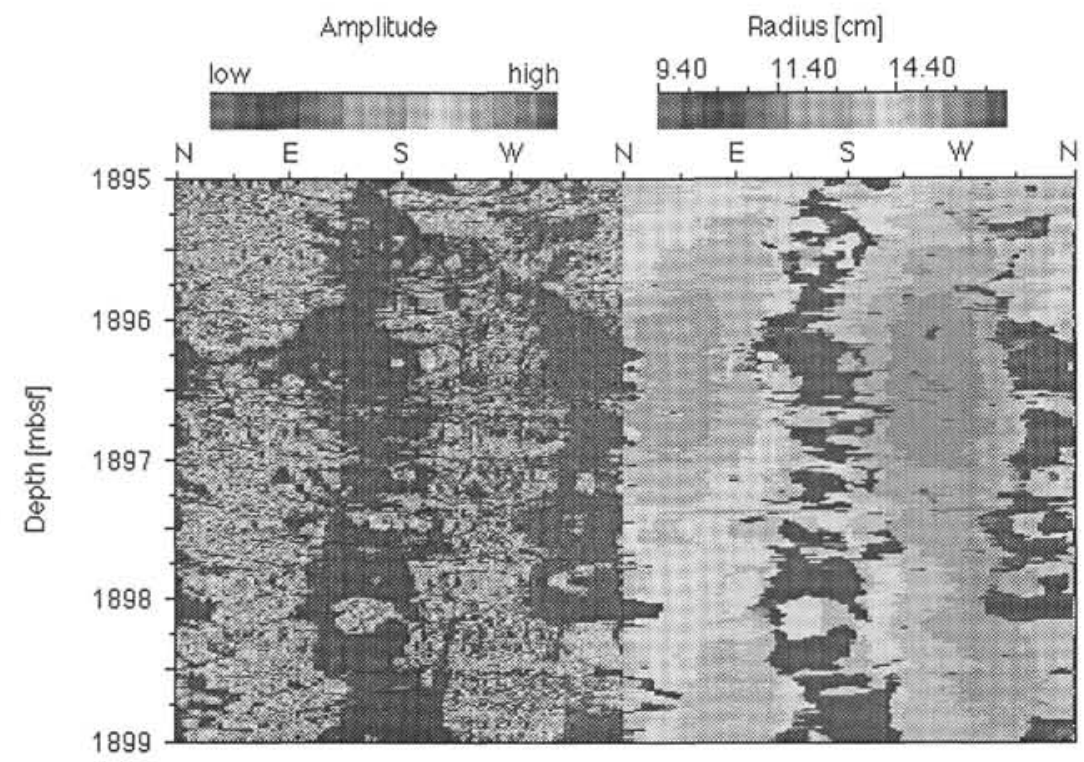

Figure 2. Borehole televiewer image from Hole 504B. Data are oriented with respect to magnetic north. Data show typical symmetrical banding of breakouts $180^{\circ}$ apart. Left: amplitude image; dark colors represent low amplitudes, bright colors high amplitudes. Right: radius image derived from traveltime data.

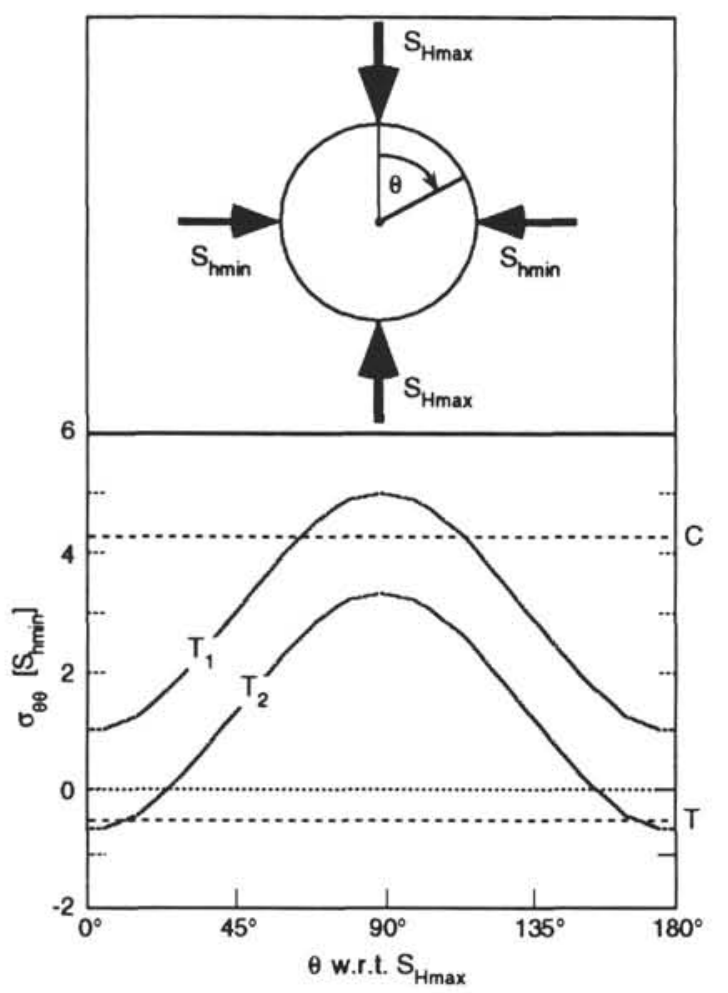

Figure 3. Circumferential stress $\sigma_{\theta \theta}$ on a circular borehole wall. Top: sketch of the nomenclature used. Bottom: variation of the circumferential stresses calculated for a $S_{\text {Hmal }} / S_{\text {limin }}$ ratio of $2 / 1 . C$ and $T$ represent the compressive and the tensile strength of the rock. In the event that $\sigma_{\theta \theta}$ exceeds the compressive rock strength, breakouts occur. $\sigma_{\theta \theta}\left(T_{l}\right)$ and $\sigma_{\theta \theta}\left(T_{2}\right)$ indicate circumferential stresses for different temperatures $T_{l}$ and $T_{2}\left(T_{l}<T_{2}\right)$ of the borehole fluid.
Table 2. Typical physical properties of basalt used for the estimation of the thermal stress $\Delta \sigma_{\theta \theta}(\Delta T)$.

\begin{tabular}{lcl}
\hline \multicolumn{1}{c}{ Parameter } & Value & Reference \\
\hline $\begin{array}{l}E \text { - Young's modulus } \\
\nu \text { - Poisson's ratio } \\
\alpha \text { - thermal expansion } \\
\text { coefficient }\end{array}$ & $70-80 \mathrm{GPa}$ & Gebrande, 1982 \\
\hline
\end{tabular}

calculation. It is obvious from these curves that under effective stress conditions the circumferential stress varies from

$$
\begin{gathered}
\sigma_{\theta \theta}=3 S_{H \max }-S_{h \min }-2 P_{p} \text {, at } \theta=90^{\circ}, 270^{\circ} \text { to } \\
\sigma_{\theta \theta}=3 S_{\text {himin }}-S_{H \max }-2 P_{p} \text { at } \theta=0^{\circ}, 180^{\circ} .
\end{gathered}
$$

Therefore, wellbore breakouts form in the direction of the least principal horizontal stress $\left(S_{h \min }\right)$, whereas tensile fractures occur in the direction of the maximum horizontal stress $\left(S_{\text {Hmax }}\right)$.

\section{THE ROLE OF THERMAL STRESS}

Wherever drilling is performed, borehole fluid is pumped down in the drill string to cool the drill bit, to reduce the friction between drill string and formation, and to raise the drilling mud or cuttings to the surface. Especially in high-temperature environments the temperature of the drilled rock can exceed the borehole fluid temperature by several tens of degrees. However, temperature differences between the borehole fluid and the drilled rock cause an additional circumferential thermal stress, which adds to the circumferential stress caused by the tectonic far-field stress (Timoshenko and Goodier, 1970; Stephens and Voight, 1982; Moos and Zoback, 1990). For substantial temperature differences $(\Delta T)$ between the borehole fluid and the formation temperature, thermally induced fractures can be initiated. Stephens and Voight (1982) proposed that thermal stresses can be critical to the fracture initiation pressure, and Apel et al. (unpubl. da- 
ta) showed that thermally induced fractures are useful stress indicators.

An analytical solution to this thermoelastical question was given by Timoshenko and Goodier (1970). In a circular cylinder the thermal stress $\left(\Delta \sigma_{\theta \theta}(\Delta T)\right)$ at the wall can be described as:

$$
\Delta \sigma_{\theta \theta}(\Delta T)=\frac{\alpha \cdot E \cdot \Delta T}{1-v}
$$

where

$\alpha=$ thermal expansion coefficient,

$E=$ Young's modulus,

$v=$ Poisson's ratio, and

$\Delta T=$ difference between borehole fluid and formation temperature.

If $\Delta T$ is positive (borehole fluid temperature exceeds formation temperature), the overall circumferential stress is compressive and destabilizes the borehole by the augmentation of existing and the initiation of new borehole breakouts (see Fig. 3). In contrast hereto, a negative temperature difference $\Delta T$ will establish extensional fractures in the borehole wall. 2.

The range of typical elastic properties of basalts is given in Table

To estimate the magnitude of the thermal stress the following values from Table 2 were used: $v=0.3, E=70 \mathrm{GPa}$, and $\alpha=5.4 \cdot 10^{-6}$ ${ }^{\circ} \mathrm{C}^{-1}$. This leads to additional thermal stresses of $\Delta \sigma_{\theta \theta}(\Delta T)=54 \mathrm{MPa} /$ $100^{\circ} \mathrm{C}$, which are compressive for positive temperature contrasts between borehole fluid and formation, and tensile for negative temperature differences.

The thermal stresses in Hole 504B are estimated from equilibrium and disturbed (temperature recording after drilling and circulation operation) temperature profiles (Fig. 4; Becker, Sakai, et al., 1988; Becker, Foss, et. al., 1992; Dick, Erzinger, Stokking, et al., 1992).

\section{DATA ANALYSIS}

During Legs 137 and 140 the depth intervals listed in Table 1 were logged with the digital BHTV. Before the stress analysis (borehole breakouts, vertical fractures), all data were corrected for magnetic declination. Depending on the vertical logging speed, the vertical spacing between BHTV data scans varied from 8 to $42 \mathrm{~mm}$ (see Table 1).

BHTV data of Leg 111 and Leg 140 overlap between 1483 and 1530 mbsf (see Table 1 and Morin et al., 1989). However, a correlation of the BHTV data from borehole wall features of Leg 140 and Leg 111 BHTV data was not possible due to jerking effects in Leg 111 data, which overprinted the data. Hence, for the following interpretation and analysis BHTV data of Leg 140 were independently treated in a first step from Leg 111 data.

Borehole breakouts (also see "Methods of Stress Evaluation" section) are identified in the BHTV images by symmetrical broad bands, which are $180^{\circ}$ apart in the amplitude as well as in the traveltime images. A typical borehole breakout interval within the sheeted dike complex, in which breakouts are observed as enlarged sections of low amplitude reflections, is shown in Figure 2. For the statistical and systematical analysis of the data, borehole cross sections were superpositioned. Depending on the vertical logging velocity, borehole cross sections of $3(v>300 \mathrm{~m} / \mathrm{h})$ to $5(v<300 \mathrm{~m} / \mathrm{h})$ scan lines were stacked (Fig. 5), and the averaged orientation and depth of borehole enlargements were determined (see also Barton et al., 1991). Vertical fractures, on the other hand, should appear as two symmetrical narrow bands, $180^{\circ}$ apart and low in amplitude compared to the surrounding rock because of scattering of the reflected signal(s). In

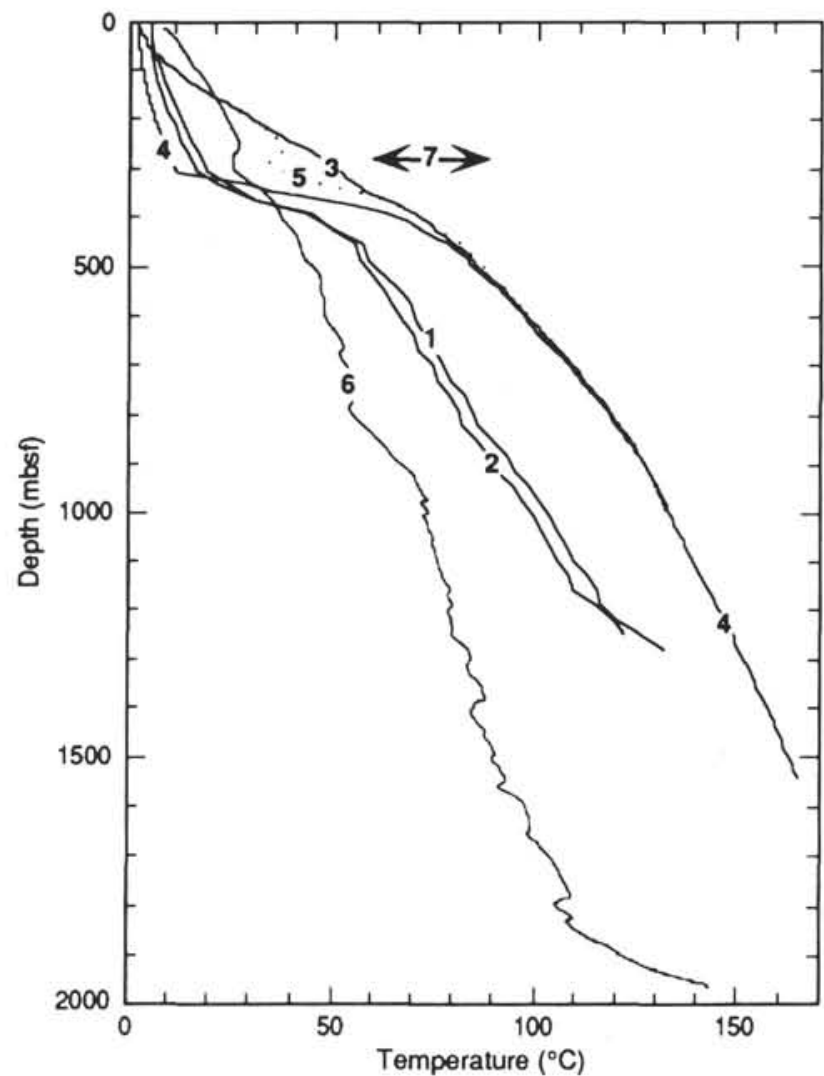

Figure 4. Composite temperature logs recorded in Hole 504B. Data is from temperature recording after first reentry if not noted otherwise. 1: Leg 83, 58 hours after drilling stopped; 2 : Leg 83,83 hours after drilling stopped; $3:$ Leg 111; 4: Leg 137; 5: Leg 140; 6: Leg 140, after drilling stopped; 7: Leg 137; temperature range from temperature sensors on the outside of the drill pipe.

contrast to borehole breakouts, vertical fractures do not show any significant change in the traveltime data.

A total of $326.5 \mathrm{~m}$ of BHTV data was investigated in the upper pillow lava section of the hole, whereas $340 \mathrm{~m}$ was available from the sheeted dike section, between 1483 and 1990 mbsf, of the lower newly drilled part of the borehole (note the data gap of $153 \mathrm{~m}$ between 1715 and 1868 mbsf; see Table 1).

Numerous stress-induced borehole breakouts occurred in the lowermost section (1497-1990 mbsf) of the drilled sheeted dike complex. Sporadic occurrence of borehole breakouts was observed in the upper basement section (pillow lava). Borehole breakouts of these depth intervals differ in character as well as in orientation, and are therefore discussed separately. Gaps in the profile represent depth sections where no wellbore failure occurred or where the reflected acoustic energy was too low to determine the shape of the borehole.

\section{Depth Interval 275-497 mbsf}

In this uppermost logged depth interval, borehole breakouts occurred below the Layer $2 \mathrm{~A} / 2 \mathrm{~B}$ boundary (Pezard and Anderson, $1989)$ in a sequence of pillow basalts and massive flows (410-490 mbsf) and $150 \mathrm{~m}$ below the top of the basement. The rock in this depth interval was highly fractured and brecciated (Cann, Langseth, Honnorez, von Herzen, White, et al., 1983) and core recovery was poor $(29 \%)$. 


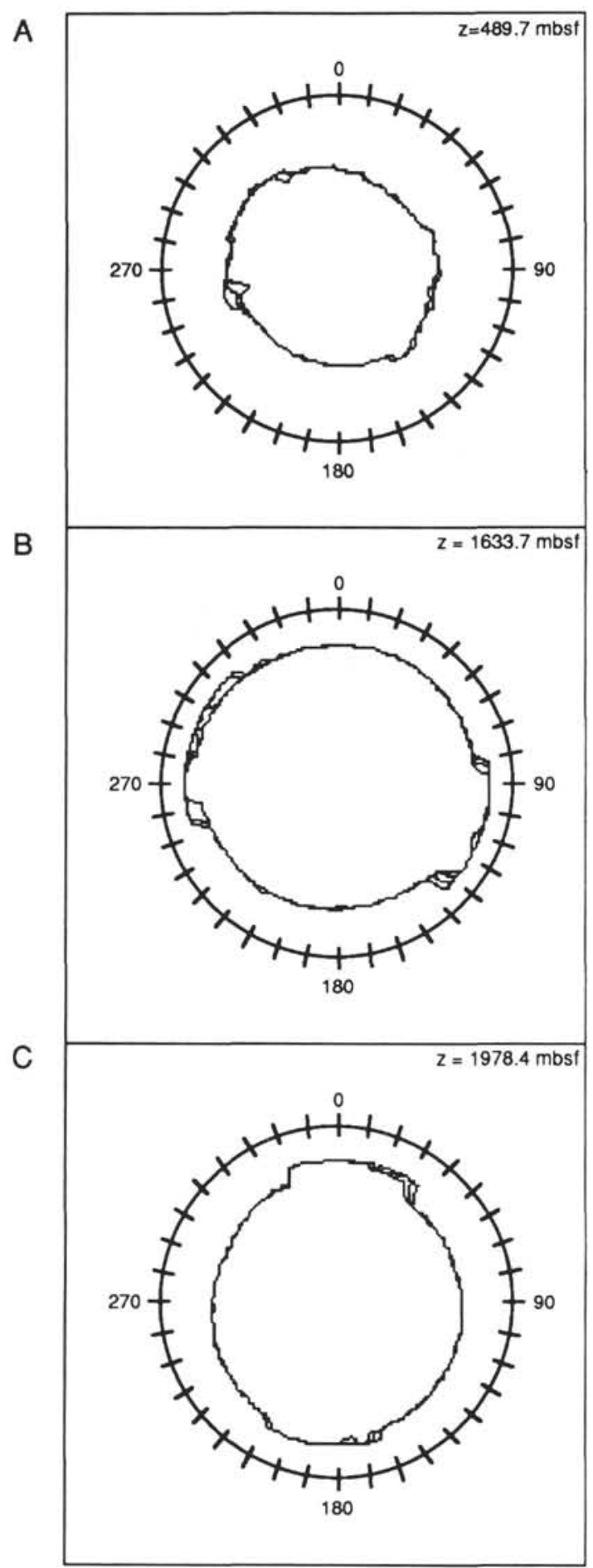

Figure 5. Borehole cross sections of BHTV measurements from different depths of ODP Legs 137 (A) and 140 (B, C) in Hole 504B. All cross sections are oriented with respect to magnetic north. Differences in borehole cross section are due to temperature and pressure effects on the borehole fluid velocities, which were not incorporated here.

Typical borehole breakout enlargements are shown in Figure 5. Individual breakout lengths were generally short, ranging from 15 to $60 \mathrm{~cm}$ in length. There were 204 borehole breakout measurements between 410 and $490 \mathrm{mbsf}$. A histogram of the azimuthal variation of these wellbore breakouts is shown in Figure 6A. The calculation of the average breakout orientation and standard deviation derived from all of these measurements, applying circular statistics (Mardia, 1972 ), is $\mathrm{N} 143^{\circ} \mathrm{E} \pm 28^{\circ}$.

\section{Depth Intervals 1497-1715 mbsf and 1868-1990 mbsf}

These two logged depth intervals are well within the lowermost part of the sheeted dike complex. Rocks at these depths are aphyric to moderately phyric diabases with strong evidence of alteration at greenschist facies. Core observation revealed abundant signs of brittle but little ductile deformation. This also is indicated by a very low average core recovery $(\approx 13 \%)$. Highly fractured zones were identified in the BHTV data in the depth intervals 1565-1585 mbsf, 16221675 mbsf, and 1935-1965 mbsf. Changing conditions of alteration and crystallization suggest that the lower part of the drilled section displays the transition zone from sheeted dikes to gabbro.

Borehole breakouts are abundant in both depth intervals. Histograms of their azimuthal variation are shown in Figures $6 \mathrm{~B}$ and $6 \mathrm{C}$. Their azimuthal variation with depth is shown in Figure 7B. They also show a marked increase in breakout number from the upper (1497-1715 mbsf) to the lower (1868-1990 mbsf) depth interval (Figs. 6B and 6C). Borehole cross sections (see Figs. 5B and 5C) show clear evidence of stress-induced borehole elongation in an otherwise circular wellbore. Breakout lengths vary from several tens of centimeters to several meters in both sections. Orientation of borehole breakouts shows a slight clockwise rotation in the upper breakout interval with an average breakout orientation of $\mathrm{N} 111^{\circ} \mathrm{E} \pm 35^{\circ}$, whereas the breakout orientations of the lower depth section are widely scattered, averaging $\mathrm{N} 172^{\circ} \mathrm{E} \pm 38^{\circ}$. The orientation of borehole elongation as derived from caliper data of the Formation Mi-

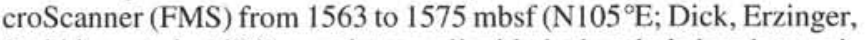
Stokking, et al., 1992) correlates well with the borehole breakout orientations observed in the same depth interval in the BHTV data.

Features similar to vertical fractures are observed from 1512 to 1525 mbsf, 1546 to 1565 mbsf, and 1905 to $1930 \mathrm{mbsf}$. However, these zones are associated with breakout zones below and above, and also match these breakout azimuths. Therefore, it is assumed that these "fractures" are not vertical tensile fractures but display the initial state of a breakout. Hence, they are not incorporated into the data interpretation and the displayed data sets.

\section{RESULTS}

\section{Results from Previous BHTV Measurements}

Legs 137 and 140 were the sixth and seventh cruises within 12 years visiting Hole 504B. Analog BHTV measurements had been conducted on Legs 69 (Anderson and Zoback, 1983) and 83 (Newmark et al., 1985), as well as on Leg 111 (Morin et al., 1989). Anderson and Zoback (1983) did not report about borehole breakout observations in the BHTV data from Leg 69 in the depth interval from 275 to 475 mbsf. Newmark et al. (1985) reported about "... the presence of breakouts at many depth intervals down the hole ..." from the investigation of BHTV data between 275 and 1350 mbsf. However, breakout analysis was restricted to the depth interval 6501000 mbsf. From the orientation of borehole breakouts within this depth section a maximum horizontal stress direction $\left(S_{H_{\max }}\right)$ of $\mathrm{N} 20^{\circ} \mathrm{E}$ was calculated. Morin et al. (1989) recorded and investigated BHTV data from 1176 to 1531 mbsf during Leg 111. Additionally, a combined reinterpretation with Leg 83 data was executed covering the complete depth interval from 700 to 1530 mbsf (Morin et al., 1990). From these analyses a mean orientation of $S_{H \text { max }}$ of N $22^{\circ} \mathrm{E}$ for the upper interval $(700-1100 \mathrm{mbsf})$ and $\mathrm{N} 24^{\circ} \mathrm{E}$ for the lower interval (1180-1530 mbsf) was determined. In the frame of their studies Morin et al. $(1989,1990)$ also reported about a “... large scatter in the borehole breakout data ..." with an abnormal distribution, which statistically could be attributed to a bimodality of the data. Whereas the primary mode was referred to the orientation of $S_{\text {hmin }}$, the secondary 
A

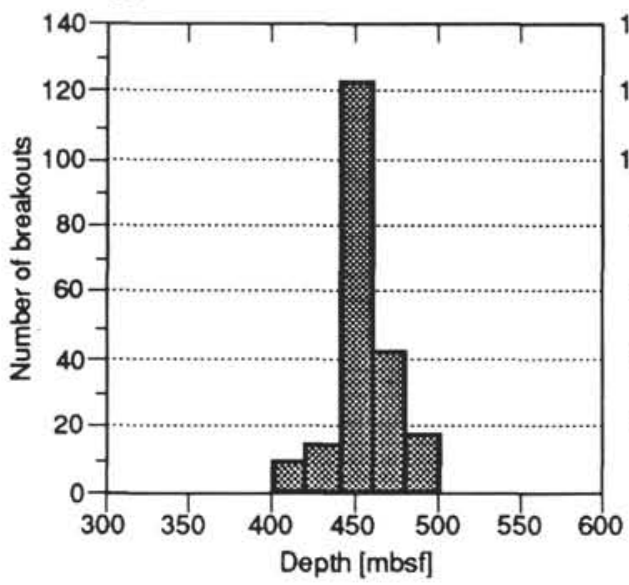

B

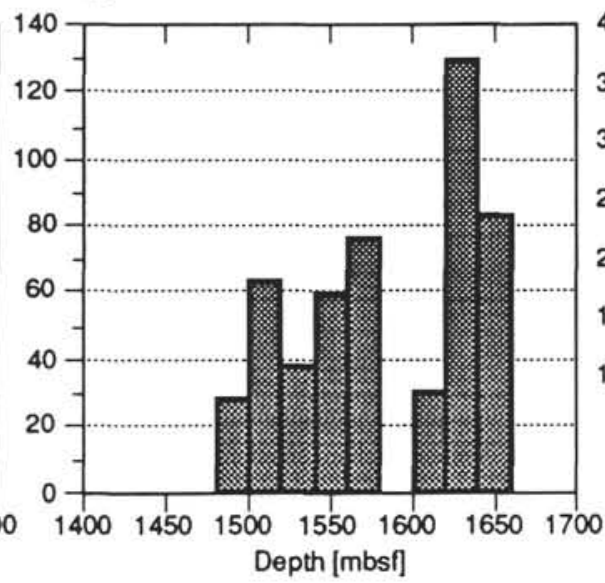

C

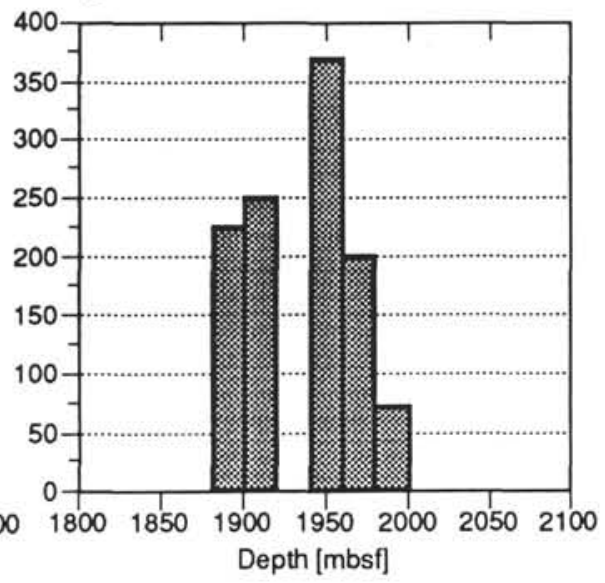

Figure 6. Borehole breakout histograms from BHTV data of Legs 137 (A) and 140 (B, C).

mode was ascribed to the $S_{\text {Hmax }}$ direction, thus the modes are $90^{\circ}$ apart. The mean orientations of $S_{\text {Himax }}$ are in good agreement with the principal stress directions derived from earthquake focal mechanisms (Bergman, 1986).

\section{Results from BHTV Analysis of Legs 137 and 140}

In the BHTV data of Legs 137 and 140 three depth intervals with borehole breakouts were observed. From the borehole breakout orientations the following mean orientations and standard deviations of the maximum horizontal stress direction $S_{\text {Hmax }}$ are derived (Table 3) using circular statistics (Mardia, 1972).

The onset of the upper breakout interval (410-490 mbsf) correlates with the start of the Layer 2A/2B transition zone (Pezard and Anderson, 1989). Previous breakout observations from Newmark et al. (1985) and Morin et al. (1989, 1990) as well as borehole breakouts in the lower depth intervals are well within the sheeted dike section (700-1750 mbsf) or in the assumed sheeted dike/gabbro transition zone, which starts at 1750 mbsf (Dick, Erzinger, Stokking, et al., 1992).

The mean of the intermediate depth section correlates well with previous results from borehole breakout observations between 700 and 1500 mbsf (Newmark et al., 1985; Morin et al., 1989, 1990). However, the means of the upper (410-490 mbsf; Table 3 ) and lower sections (1868-1990 mbsf; Table 3) are rotated clockwise by several tens of degrees to these results (compare Figs. 7A, -B). For the lowermost investigated depth section (1868-1990 mbsf) a bimodality as suggested by Morin et al. (1989, 1990) is only weakly indicated (see the approximate $90^{\circ}$ difference of the peaks in the histograms of Fig. $8 \mathrm{~A})$.

\section{Information from Modeling and Tectonic Forces}

Hole 504B is situated approximately $200 \mathrm{~km}$ south of the Costa Rica Rift, $400 \mathrm{~km}$ west of the Peru-Chile Trench, and more than 2000 $\mathrm{km}$ east of the East Pacific Rise. Its location in the northeastern part of the Nazca Plate is within a region of complex interaction of spreading centers, subduction zones, and transform faults (Richardson and Cox, 1984; Wortel and Cloetingh, 1985).

Wortel and Cloetingh (1985), modeling the Nazca Plate with finite element methods, calculated an east-west- to east-northeastwest-southwest-directed horizontal compressional stress regime in the northern part of the Nazca Plate with magnitudes on the order of $40 \mathrm{MPa}$. However, this model was very simplified in the area of our investigation.
Stress directions inferred from centroid moment tensor solutions of the years 1977-1990 (Dziewonski, et al., 1983a, b; 1984a, b; 1986; 1987a-d; 1988a-d; 1989a-c; 1990) and detailed investigation of earthquake focal mechanisms (Bergman, 1986) show predominantly strike-slip regime in the area of investigation with a northeast-southwest-trending orientation of $S_{H \max }\left(\mathrm{N} 51^{\circ} \mathrm{E} \pm 17^{\circ}\right)$. Furthermore, the strike-slip regimes indicate that the maximum and principal horizontal stresses are the maximum and minimum principal stresses, whereas the vertical stress $\left(S_{v}\right)$ is intermediate $\left(S_{h \min } \leq S_{v} \leq S_{\text {Hmax }}\right)$. Figure 9 shows the mean orientations of $S_{H \max }$ determined from BHTV analysis in the three depth intervals in the context of the maximum horizontal principal stress direction inferred from focal mechanisms and the regional tectonic setting.

\section{Magnitude Estimates Deduced from Breakout Occurrence}

Observations of breakout occurrence allow not only the determination of the orientation of the principal horizontal stresses, but also estimates of the principal stress magnitudes. Moos and Zoback (1990) proposed a model to constrain the range of stress magnitudes and conditions for borehole breakouts to occur. For this model the following assumptions apply:

1. The rock material is isotropic and behaves elastically.

2. The pore pressure $\left(P_{p}\right)$ of the formation is hydrostatic:

$$
P_{p}=\rho_{w} \cdot g \cdot \sum_{i} h_{i}
$$

with the water density $\rho_{w}$, the acceleration of gravity $g$, and the layer thicknesses $h_{i}$.

3. The frictional coefficient $\mu$ in preferentially oriented planes of weakness limits the strength of the crust.

If these assumptions apply, the Coulomb criterion for optimally oriented faults (Jaeger and Cook, 1979) suggests that

$$
\frac{\left(S_{1}-P_{p}\right)}{\left(S_{3}-P_{p}\right)}=\left\{\sqrt{1+\mu^{2}}+\mu\right\}^{2}
$$

with the maximum principal stress $\mathrm{S}_{1}$, and the minimum principal stress $S_{3}$. Incorporating information on the type of the present-day tectonic stress regime according to Anderson (1951; see Table 4) 
A

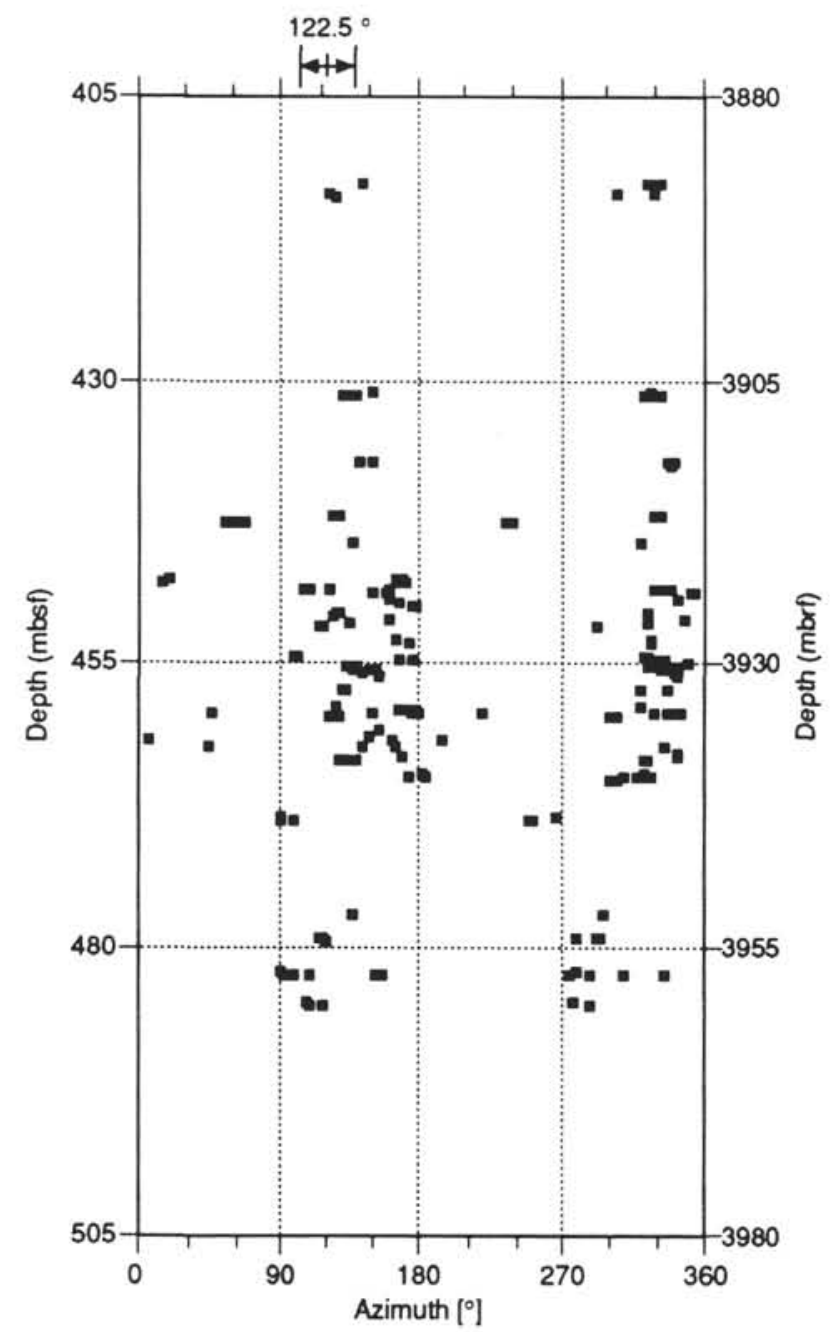

B

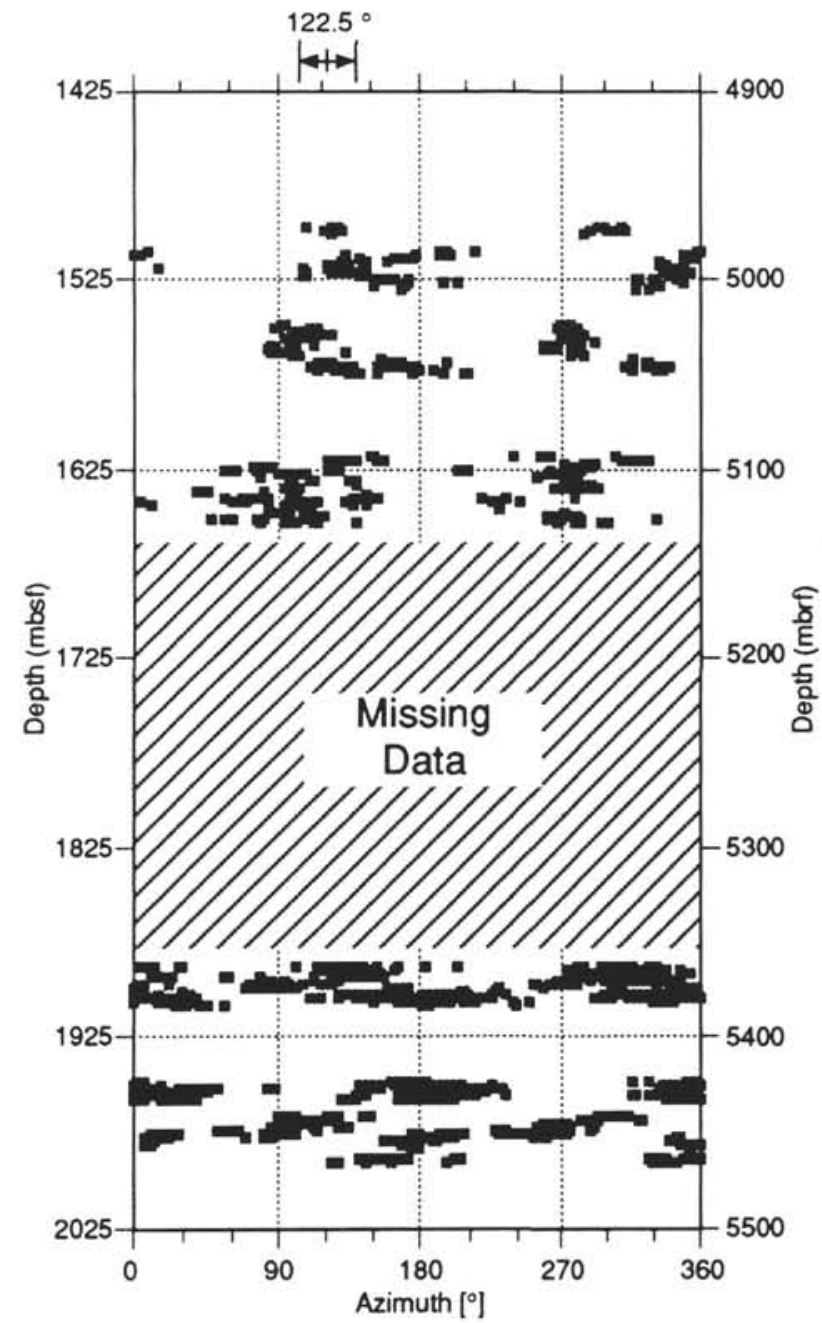

Figure 7. Variation of borehole breakout distribution with depth in Hole 504B from BHTV data recorded on Legs 137 (A) and 140 (B). Note the different depth scales. Bars on top show the mean and standard deviation of $S_{h m i n}$ as derived from Morin et al. (1989).

into Equation 7, and assuming that the vertical stress $\left(S_{v}\right)$ is a principal stress and corresponds to the vertical overburden:

$$
S_{v}=g \cdot \sum_{i} \rho_{i} \cdot h_{i}
$$

with the densities $\left(\rho_{i}\right)$ and the thicknesses $\left(h_{i}\right)$ of the different layers, the stress magnitude can be calculated as a function of depth. Information on the stress regime in the area of investigation can be obtained from earthquake focal mechanisms or any other (geological) stress indicator. Table 5 shows the density-depth values (Dick, Erzinger, Stokking, et al., 1992) used for the calculation of possible ranges of stress magnitudes.

Byerlee (1978) showed that frictional strength of rocks varies in between: $\mu=0.6-0.85$. The range of stress magnitudes for an extensional (NF) and compressional (TF) stress regime is displayed in Figure 10 assuming a frictional coefficient of $\mu=0.8$. The magnitude of $S_{H_{\max }}$ is between $S_{h \min }$ and $S_{v}$ for a NF regime and $S_{v}$ and $S_{H_{\max }}$ for a TF regime. The range of magnitudes would shrink for lower values of $\mu$
Table 3. Maximum horizontal stress direction derived from borehole breakouts.

\begin{tabular}{cc}
\hline $\begin{array}{c}\text { Depth interval } \\
\text { (mbsf) }\end{array}$ & $\begin{array}{c}S_{\text {Hata }}\left(\mathrm{N}^{\circ} \mathrm{E}\right) \\
\text { orientation }\end{array}$ \\
\hline $410-490$ & $53^{\circ} \pm 28^{\circ}$ \\
$1497-1715$ & $21^{\circ} \pm 35^{\circ}$ \\
$1868-1990$ & $82^{\circ} \pm 38^{\circ}$ \\
\hline
\end{tabular}

and expand for higher values, respectively. Calculations of the circumferential stress for NF and TF stress regimes show that for assumed NF conditions stress magnitudes are too low to create borehole breakouts in one of the depth intervals where breakouts were observed (see Fig. 10).

\section{Breakout Occurrence and Stress Magnitude}

BHTV data of Legs 137 and 140 revealed sporadic borehole breakouts in depths of about $450 \mathrm{mbsf}$, and numerous borehole breakouts in the lower depth intervals (1497-1715 mbsf and 1868- 
A
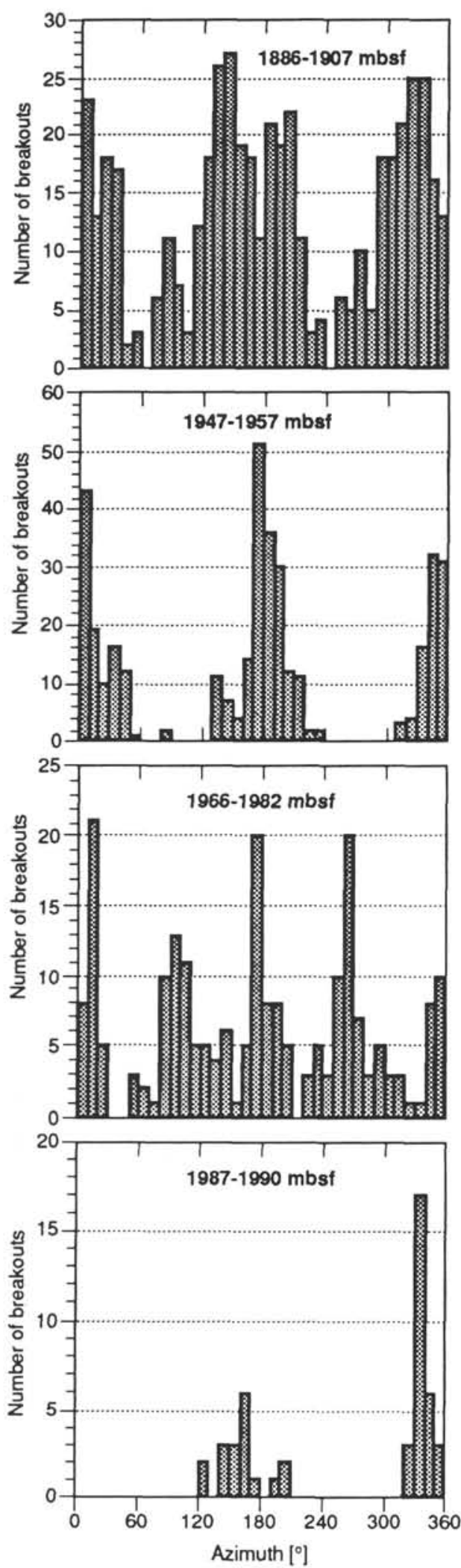

B
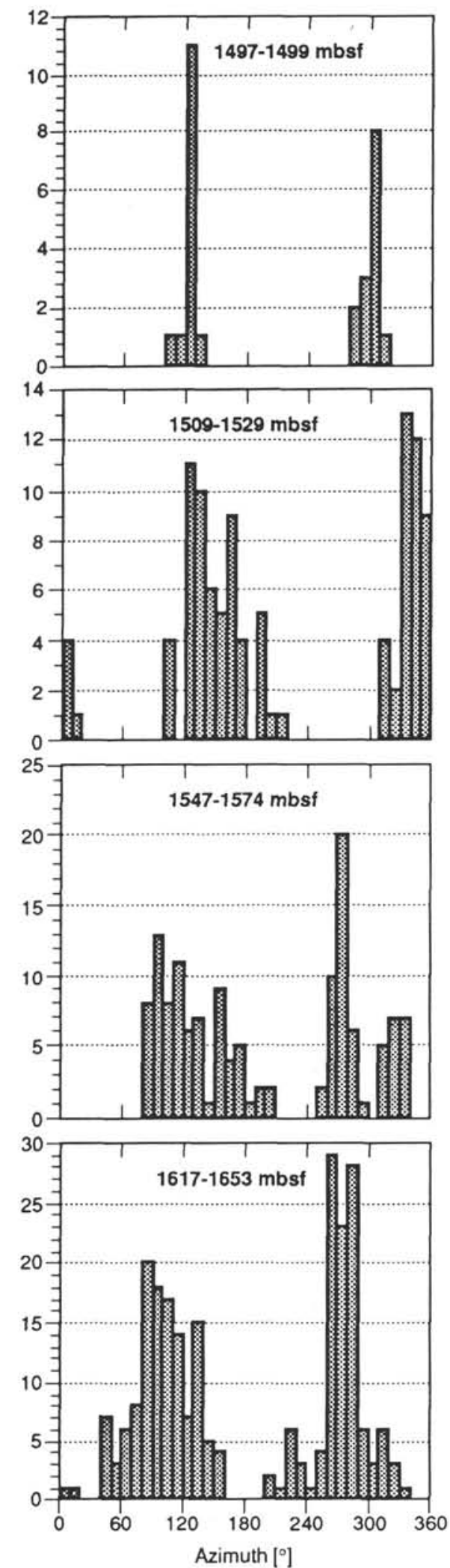

Figure 8. Detailed borehole breakout histograms. A. Depth interval 1886-1990 mbsf. B. Depth interval 1497-1653 mbsf. 


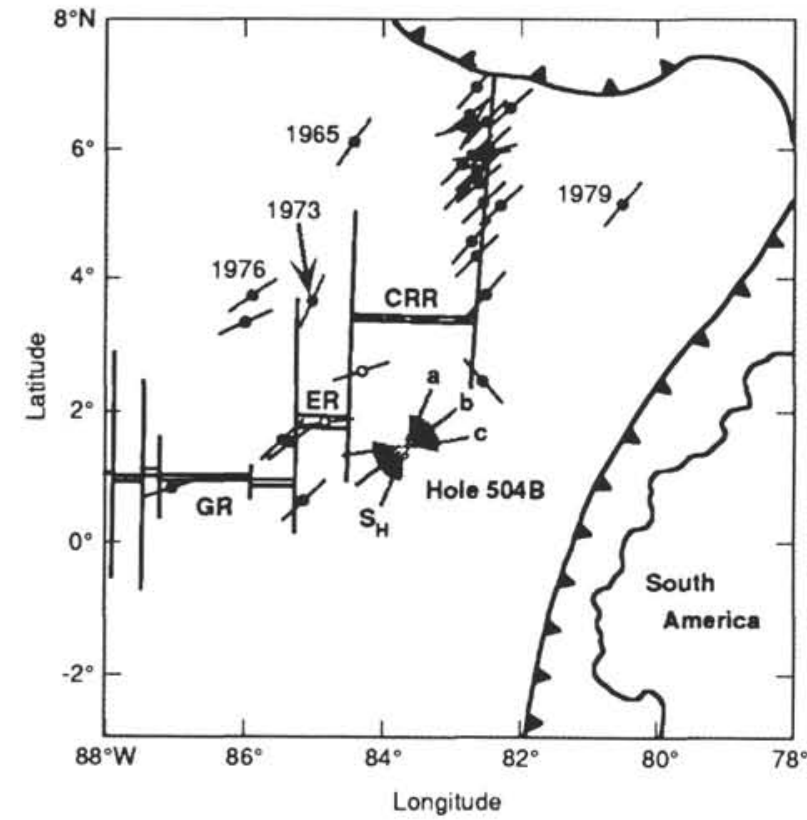

Figure 9. Orientation of maximum horizontal stress $S_{H \max }$ in the area of investigation as deduced from centroid moment tensor solutions (Dziewonski et al., 1983a, b, 1984a, b, 1986, 1987a-d, 1988a-d, 1989a-c, 1990; Bergman, 1986) and borehole data investigation $(a, b, c)$ of this study. Bars indicate the orientation of $S_{\text {Himax }}$ derived from centroid moment tensor solutions. Filled circles $=$ strike-slip faulting regime; open circles $=$ normal faulting regime. Data marked with year of occurrence are from Bergman (1986). Orientation of $S_{H \max }$ from borehole breakout depth intervals: a. 410-490 mbsf; b. 1497-1715 mbsf; c. 1868-1990 mbsf. CRR = Costa Rica Rift; ER = Ecuador Rift; GR = Galapagos Rift.

$1990 \mathrm{mbsf}$ ). Because of the tectonic regime indicated by the fault plane solutions, stress magnitudes for various borehole conditions (pore pressure, temperature effects, etc.) were calculated under the assumption of a TF/SS regime (see Fig. 10). Figure 11 shows the variation of the circumferential stress for those depths where borehole breakouts occurred. Included into this figure is the range of measured uniaxial unconfined compressive strength $\left(C_{0}=140-250 \mathrm{MPa}\right)$ as determined from Bauer and Handin (1985) and Christaras (this volume). A detailed description of the testing procedure is given in the references above.

\section{$410-490 \mathrm{mbsf}$}

Figure 11A clearly verifies that under "normal" crustal conditions $\left(\mu=0.6-0.85\right.$ [Byerlee, 1978], $P_{p}=$ hydrostatic) and "typical" rock strengths of basalt (Carmichael, 1982) borehole breakouts as seen in this depth (Fig. 5A) should not occur. A possible explanation for this phenomenon are small-scale changes in the compressive rock strength. Additionally, we investigated temperature and pore pressure effects (see Equations 4-6), which also affect borehole failure.

To account for the effects of borehole fluid temperature on breakout and/or vertical fracture initiation, temperature measurements from several previous legs (see Fig. 4) were incorporated. When the cold drilling fluid exits the drill pipe, the negative temperature contrast between fluid and formation temperature can account for the occurrence of fractures. While moving up the annulus, the borehole fluid will be heated by internal friction, conductive and possibly convective heat transfer from the formation until it reaches the "zero point," where borehole fluid and formation temperature equal. Above this point, the borehole fluid temperature is higher than formation
Table 4. Classification of tectonic stress regimes according to Anderson (1951).

\begin{tabular}{cl}
\hline Regime & Relative stress magnitude \\
\hline $\mathrm{NF}$ & $S_{1}=S_{\mathrm{v}}>S_{2}=\mathrm{S}_{H}>S_{3}=\mathrm{S}_{4}$ \\
$\mathrm{TF}$ & $S_{1}=\mathrm{S}_{H}>S_{2}=\mathrm{S}_{\mathrm{H}}>S_{3}=S_{\mathrm{r}}$ \\
$\mathrm{SS}$ & $S_{i}=\mathrm{S}_{H}>S_{2}=S_{y}>S_{3}=S_{h}$ \\
\hline
\end{tabular}

Table 5. Depth intervals and densities from shipboard measurements used for the calculation of stress regimes and magnitudes in Hole 504B.

\begin{tabular}{rc}
\hline$z$ (mbsl) & $\rho\left(\mathrm{kg} / \mathrm{m}^{3}\right)$ \\
\hline $0-3465$ & 1030 \\
$3465-3740$ & 1400 \\
$3740-\mathrm{BOH}$ & 2900 \\
\hline
\end{tabular}

Note: $\mathrm{BOH}=$ bottom of hole; $\mathrm{mbsl}=$ meters below sea level.

temperature, and therefore supports the creation of breakouts. Temperature logs recorded shortly after the drilling operations range from $40^{\circ} \mathrm{C}$ ( $\left.450 \mathrm{mbsf}\right)$ to $75^{\circ} \mathrm{C}$ ( $\left.1600 \mathrm{mbsf}\right)$ below the formation temperature (equilibrium temperature, graphs 1 and 4). Those temperatures would account for additional thermal, tensile stresses on the order of $\Delta \sigma_{\theta \theta}(\Delta T)=-17 \mathrm{MPa}(450 \mathrm{mbs})$ and $\Delta \sigma_{\theta \theta}(\Delta T)=-32 \mathrm{MPa}(1600$ mbsf) and facilitate the formation of thermally induced vertical fractures. However, vertical fractures were not observed. Additionally, it is known from temperature sensitive labels, which were placed on the outside of the drill string at $250 \mathrm{mbsf}$, that the temperature of the water in the annulus is on the order of $60^{\circ} \mathrm{C}$ to $90^{\circ} \mathrm{C}$ at this depth (Foss, pers. comm., 1991). Such temperatures would lead to an additional, compressive thermal stress of $\Delta \sigma_{\theta \theta}(\Delta T)=22$ to $35 \mathrm{MPa}$ (for $\Delta T$ between $40^{\circ} \mathrm{C}$ and $65^{\circ} \mathrm{C}$ ) and facilitate the formation of borehole breakouts at that depth. However, the thermal stress is too low to cause breakouts as indicated by the curve labeled with $\mu=0.8$ and $\Delta T=$ $40^{\circ} \mathrm{C}$ in Figure $11 \mathrm{~A}$, which does not exceed the rock strength. Thus, in a further step, the effect of pore pressure variation was investigated.

It is known from hydraulic tests (Zoback and Anderson, 1983) and various geothermal measurements (e.g., downhole flow of oceanic bottom water due to underpressure in the permeable, uppermost basement; Becker et al., 1985; Gable et al., 1989) that the pore pressure is subhydrostatic by $2.5 \%$ in Hole 504B. However, for a relevant pore pressure effect on the frictional stress, the pore pressure needs to be subhydrostatic by at least $20 \%$ (Fig. 11A). If it is assumed that the frictional coefficient $\mu$ is in the range 0.6-0.85 (Byerlee, 1978) and rock strength is within "typical" values of basalt, then the combined interaction of about $20 \%$ subhydrostatic pore pressure and at least additional thermal compressive stress of $40-50 \mathrm{MPa}$, which is equivalent to about $100^{\circ} \mathrm{C}$, would be necessary to create borehole breakouts. Whereas borehole fluid might be in this temperature range, a $20 \%$ subhydrostatic pore pressure is extremely high and is highly speculative for this wellbore. But changing temperature profiles observed over time in the uppermost basement indicate that pressure conditions are different from expectations (Becker, Foss, et al., 1992), and little is known about the effect of pressure drop in the formation due to pipe trips and drill pipe withdrawal.

\section{$1497-1715$ and $1868-1990 \mathrm{mbsf}$}

Figures $11 \mathrm{~B}$ and $11 \mathrm{C}$ illustrate that borehole breakouts will form in depths below $1600 \mathrm{mbsf}$ for all calculated stress conditions. For all conditions the strength of the basalt is exceeded, which explains increasing breakout number with depth (Fig. 6; Morin et al., 1989). Also for $\mu>0.6$ tensile stresses arise. 


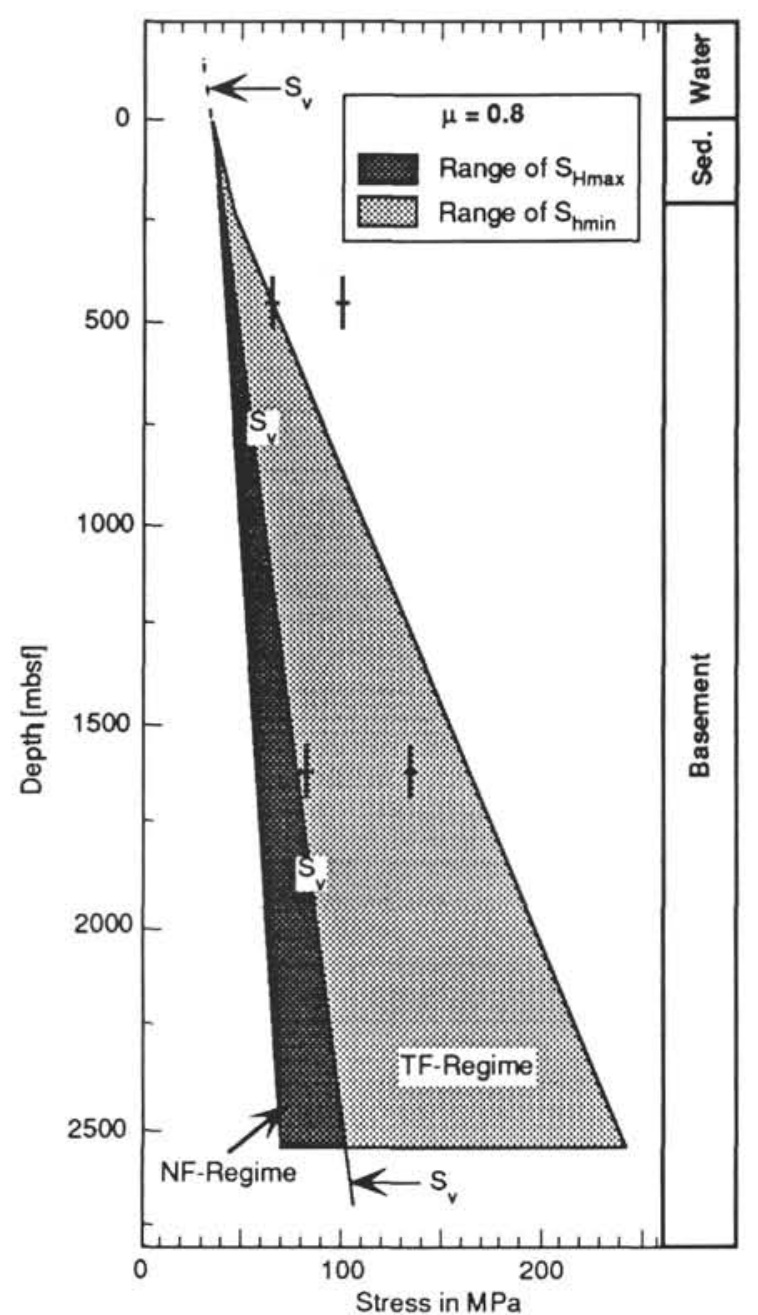

Figure 10. Range of estimated stress magnitudes with depth for a NF and a TF regime applying Moos and Zoback (1990). Indicated with vertical bars are the limits of the calculated minimum and maximum horizontal stresses for depths at $450 \mathrm{mbsf}$ and $1600 \mathrm{mbsf}$.

The striking feature in these lower depth sections is the apparent "rotation" of breakout orientation with depth (Fig. 7) and/or the existence of bimodality in the BHTV data (Figs. 8A and 8B). Morin et al. $(1989,1990)$ ascribed the existence of bimodal modes, $90^{\circ}$ apart in the BHTV data, with the existence of thermally induced fractures. As shown above (Figs. 11B and 11C; Fig. 4) tensile stresses are present. However, as described above, features that could be uniquely associated to vertical fractures were not observed.

Different explanations for rotation of borehole breakout orientation have been given: (1) Blümling (1986) proposed azimuthal borehole breakout variations as a consequence of the anisotropy of the surrounding rock, as it is observed in foliated rock (Mastin et al., 1991); (2) Shamir and Zoback (1992) consider small- and wide-scale borehole breakout rotations in the vicinity of fault zones intersecting the wellbore. This is in agreement with finite element modeling of stress refraction on inclined faults as shown by Stephansson et al. (1991) and Clauss (1988). However, none of the rotated borehole breakout intervals observed in the BHTV data of this study correlate directly with structures intersecting the wellbore up to a depth of $2000 \mathrm{mbsf}$. Indication for any kind of material anisotropy is given by Agar (1990) and by seismic measurements for the upper $500 \mathrm{~m}$ of the basement (Stephen, 1985), which therefore could account for the ob-

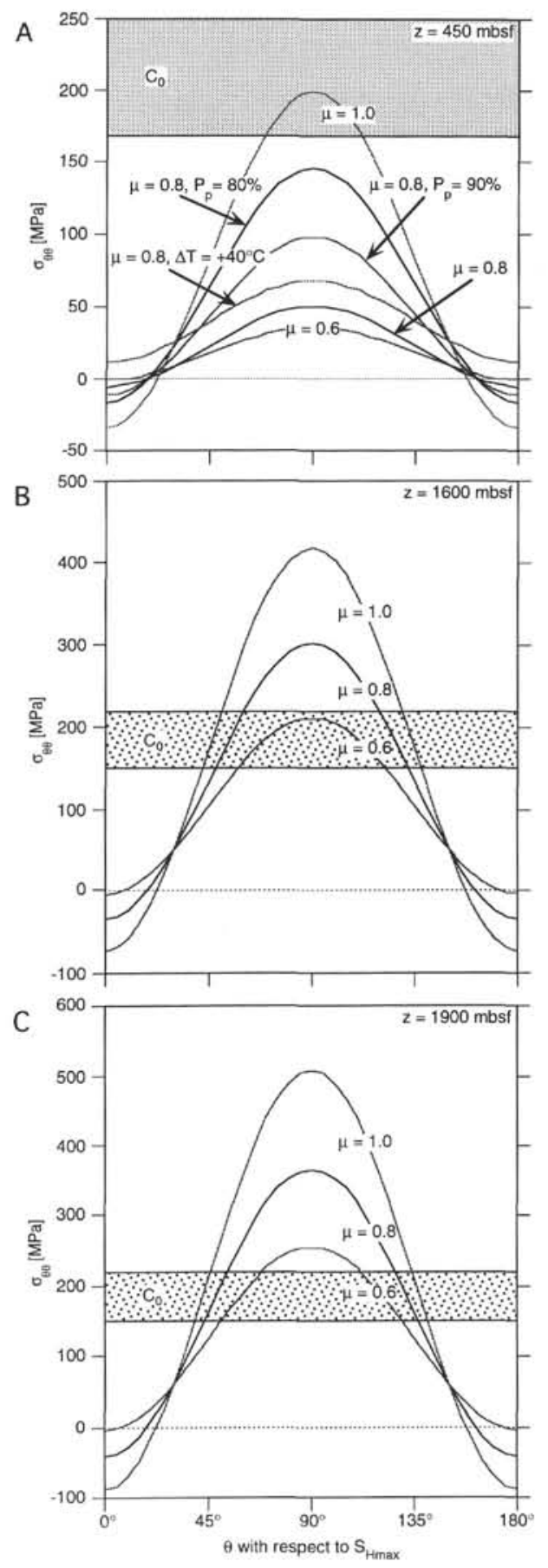

Figure 11. Circumferential stresses with respect to the maximum horizontal stress $S_{\text {Hmax }}$ at various depths in Hole 504B for a reverse fault/strike slip (TF/ SS) regime. Different coefficients of friction $(\mu)$ were used for the calculations. If not described otherwise, pore pressure of the formation $\left(P_{p}\right)$ is assumed to be hydrostatic, and temperature difference $(\Delta T)$ between wellbore fluid and formation is zero. Range of measured uniaxial compressive strength $\left(C_{0}\right)$ is marked as dotted zones. Breakouts should occur when the circumferential stress exceeds the compressive strength of the rock (dotted zone). Tensile fractures should develop when the tensile strength of the rock is exceeded. A. Circumferential stresses in $450 \mathrm{mbsf}$ for different frictional coefficients, temperature differences, and pore pressure of the formation. Rock strength after Bauer and Handin (1985). B. Circumferential stresses in 1600 mbsf. C. Circumferential stresses in 1900 mbsf. Rock strength for (B) and (C) after Christaras (this volume). 
served offset of the breakout orientation in the depth interval 410 490 mbsf. The noncorrelation of any structural observation in the BHTV data with borehole breakout observations suggests one or several major faults in the vicinity of the borehole that are either steeply dipping and therefore not intersecting $504 \mathrm{~B}$, or are beyond the present total depth of Hole 504B. If the latter explains the present borehole breakout observations, this major fault might be associated with the assumed sheeted dike/gabbro transition.

\section{Stress Magnitudes}

The existence of borehole breakouts and the absence of tensile fractures in the BHTV data of Hole 504B allow the estimate of stress magnitudes from Equations $1 \mathrm{~A}-\mathrm{B}, 4$, and 5. They form into $\sigma_{\theta \theta}=$ $3 S_{H_{\text {max }}}-S_{\text {tumin }}-2 P_{p}+\Delta \sigma_{\theta \theta}(\Delta T)>C$, for breakouts to occur, and $\sigma_{\theta \theta}=$ $3 S_{\text {lmint }}-S_{\text {Himar }}-2 P_{p}+\Delta \sigma_{\theta \theta}(\Delta T)>-T$, for tensile failure not to occur. For the calculations of the thermal stresses (see above), an average compressive strength of $C=200 \mathrm{MPa}$ and a tensile strength of $T=20$ $\mathrm{MPa}(1 / 10$ of $C)$ for the basalt drilled were assumed. Then the horizontal stress magnitudes should range from $S_{\text {lmin }} \geq 65 \mathrm{MPa}$ to $S_{\text {Hmax }} \leq$ $103 \mathrm{MPa}$ in $450 \mathrm{mbsf}$, and $S_{\text {imain }} \geq 96 \mathrm{MPa}$ to $S_{H_{\text {max }}} \leq 131 \mathrm{MPa}$ in 1600 mbsf. These values were incorporated into Figure 10 and clearly show that they are well within the range of the assumed TF regime at $1600 \mathrm{mbsf}$. At that depth, using $\mathrm{S}_{1}=S_{H_{\text {max }}}=131 \mathrm{MPa}$ and $S_{3}=S_{1}=$ $78 \mathrm{MPa}$, Equation 7 provides a frictional coefficient of about $\mu=0.6$, which agrees well with laboratory tests from Byerlee (1978). At the depth of $450 \mathrm{mbsf}$, using the same value of $\mu$ and $S_{3}=S_{v}=48 \mathrm{MPa}$ (TF/SS regime), hydrostatic pore pressure conditions and a maximum thermal stress $\Delta \sigma_{\theta \theta}(\Delta T)=+30 \mathrm{MPa}$, a value of $S_{\text {Himax }}$ close to 65 $\mathrm{MPa}$ is obtained. The occurrence of breakouts under these conditions requires strongly reduced rock strengths, which should be less than $100 \mathrm{MPa}$ in the uppermost massive flows and pillow lavas.

\section{CONCLUSIONS}

Three intervals with borehole breakouts were found by the analysis of BHTV data from Legs 137 and 140 of Hole 504B in the eastern equatorial Pacific. The borehole breakout orientation of $\mathrm{N} 53^{\circ} \mathrm{E}$ in the interval $410-490$ mbsf agrees well with a seismic anisotropy observed within the upper $500 \mathrm{~m}$ of Hole 504B. The occurrence of borehole breakouts in such shallow depths implies that there is either a high $S_{\text {Hmax }} / S_{\text {hmä }}$ ratio (associated with a high frictional strength) or a locally reduced rock strength.

The intermediate interval (1497-1715) shows a stress orientation of N2 $1{ }^{\circ} \mathrm{E}$, which is consistent with earlier observations of Morin et al. (1989). To greater depths the borehole breakouts rotate, and in 1868-1990 mbsf the mean stress orientation is N82 ${ }^{\circ} \mathrm{E}$. There is no obvious structural evidence in the BHTV data for such a rotation. However, even non-intersecting structures and structures beyond the present wellbore depth (e.g., associated with the sheeted dike/gabbro transition) may affect the breakout and apparent stress orientation as suggested by numerical and analytical studies (Shamir and Zoback, 1992; Stephansson et al., 1991).

\section{ACKNOWLEDGMENTS}

This work was supported by the Deutsche Forschungsgemeinschaft (DFG, grant Fu 55/32-2, 3). The DFG also enabled data recording by the kind provision of a digital borehole televiewer. We also thank B. Müller and M. Brudy for thoughtful and helpful discussions, and for a prereview of the manuscript. We thank M. Zoback (Stanford University), who provided the BHTV analysis program to the Geophysical Institute at the University of Karlsruhe, and C.A. Barton for her efforts on writing this program. We also are very thankful to B. Christaras for providing the compressive strength data. Last but not least, we appreciate the thorough and thoughtful comments of Dr. A. McGarr and one unknown reviewer, which considerably improved this article.

\section{REFERENCES ${ }^{*}$}

Agar, S.M., 1990. Fracture evolution in the upper ocean crust: evidence from DSDP Hole 504B. In Knipe, R.J., and Rutter, E.H. (Eds.), Deformation Mechanisms, Rheology and Tectonics. Geol. Soc. Spec. Publ. London, $54: 41-50$

Anderson, E.M., 1951. The Dynamics of Faulting and Dike Formation with Applications in Britain (2nd ed.): Edinburgh (Oliver and Boyd).

Anderson, R.N., Honnorez, J., Becker, K., et al., 1985. Init. Repts. DSDP, 83: Washington (U.S. Govt. Printing Office).

Anderson, R.N., and Zoback, M.D., 1983. The implications of fracture and void distribution from bore-hole televiewer imagery for the seismic velocity of the upper oceanic crust at Deep Sea Drilling Project Holes 501 and 504B. In Cann, J.R., Langseth, M.G., Honnorez, J., Von Herzen, R.P., White, S.M., et al., Init. Repts. DSDP, 69: Washington (U.S. Govt. Printing Office), 255-270.

Barton, C.A., Tessler, L., and Zoback, M.D., 1991. Interactive analysis of borehole televiewer data. In Palaz, I., and Sengupta, S. (Eds.), Automated Pattern Analysis in Petroleum Exploration: New York (Springer Verlag), $217-242$

Bauer, S.J., and Handin, J., 1985. Mechanical properties of basalt cores from Deep Sea Drilling Project Hole 504B. In Anderson, R.N., Honnorez, J., Becker, K., et al., Init. Repts. DSDP, 83: Washington (U.S. Govt. Printing Office), 371-375.

Becker, K., Foss, G., et al., 1992. Proc. ODP, Init. Repts., 137: College Station. TX (Ocean Drilling Program).

Becker, K., Langseth, M.G., Von Herzen, R.P., Anderson, R.N., and Hobart, M.A., 1985. Deep crustal geothermal measurements, Hole 504B, Deep Sea Drilling Project Legs 69, 70, 83, and 92. In Anderson, R.N., Honnorez, J., Becker, K., et al., Init. Repts. DSDP, 83: Washington (U.S. Govt. Printing Office), 405-418.

Becker, K., Sakai, H., et al., 1988. Proc. ODP, Init. Repts., 111: College Station, TX (Ocean Drilling Program).

Bell, J.S., and Gough, D.I., 1979. Northeast-southwest compressive stress in Alberta: evidence from oil wells. Earth Planet. Sci. Lett., 45:475-482.

Bergman, E.A., 1986. Intraplate earthquakes and the state of stress in oceanic lithosphere. Tectonophysics, 132:1-35.

Blümling. P., 1986. In-situ Spannungsmessungen in Tiefbohrungen mit Hilfe von Bohrlochrandausbrüchen und die Spannungsverteilung in der Kruste Mitteleuropas und Australiens [Ph.D. dissert.]. Univ. Karlsruhe.

Byerlee, J.D., 1978. Friction of rocks. Pure Appl. Geophys., 116:615-626.

Cann, J.R., Langseth, M.G., Honnorez, J., Von Herzen, R.P., White, S.M., et al., 1983. Init. Repts. DSDP, 69: Washington (U.S. Govt. Printing Office).

Carmichael, R.S., 1982. Handbook of Physical Properties of Rocks (Vol. 2): Boca Raton, Fla. (CRC Press).

Clauss, B., 1988. Numerische Modellierung der tektonischen Spannungen in der Nordschweiz [Diploma thesis]. Univ. Karlsruhe.

Dick, H.J.B., Erzinger, J., Stokking, L.B., et al., 1992. Proc. ODP, Init. Repts., 140: College Station, TX (Ocean Drilling Program).

Dziewonski, A.M., Ekström. G., Franzen, J.E., and Woodhouse, J.H., 1987a. Centroid-moment tensor solutions for April-June 1986. Phys, Earth Planet. Inter., 45:229-239.

1987b. Centroid-moment tensor solutions for July-September 1986. Phys, Earth Planet. Inter., 46:303-315.

1987c. Global seismicity of 1978: centroid-moment tensor solutions for 512 earthquakes. Phys. Earth Planet. Inter., 50:316-342.

1987d. Global seismicity of 1977: centroid-moment tensor solutions for 471 earthquakes. Phys. Earth Planet. Inter, 50:11-36.

, 1988a. Global seismicity of 1980: centroid-moment tensor solutions for 515 earthquakes. Phys. Earth Planet. Inter., 50:127-154.

1988b. Global seismicity of 1981: centroid-moment tensor solutions for 542 earthquakes. Phys. Earth Planet. Inter., 50:155-182.

\footnotetext{
Abbreviations for names of organizations and publications in ODP reference lists follow the style given in Chemical Abstracts Service Source Index (published by American Chemical Society).
} 
Dziewonski, A.M., Ekström. G., Woodhouse, J.H., and Zwart, G., 1988c. Centroid-moment tensor solutions for January-March 1987. Phys. Earth Planet. Inter, 50:116-126.

1988d. Centroid-moment tensor solutions for July-September 1987. Phys. Earth Planet. Inter., 53:1-11

1989a. Centroid-moment tensor solutions for October-December 1987. Phys, Earth Planet. Inter, 54:10-21.

, 1989b. Centroid-moment tensor solutions for January-March 1988. Phys. Earth Planet. Inter., 54:22-32.

, 1989c. Centroid-moment tensor solutions for April-June 1988. Phys. Earth Planet. Inter. 54:199-209.

1990. Centroid-moment tensor solutions for January-March 1989. Phys. Earth Planet. Inter., 54:233-242.

Dziewonski, A.M., Franzen, J.E., and Woodhouse, J.H., 1983a. Centroidmoment tensor solutions for April-June 1983. Phys. Earth Planet. Inter., $33: 243-249$.

1984a. Centroid-moment tensor solutions for July-September 1983. Phys. Earth Planet. Inter., 34:1-8.

1984b. Centroid-moment tensor solutions for October-December 1983. Phys. Earth Planet. Inter., 34:129-136.

1986. Centroid-moment tensor solutions for April-June 1985. Phys. Earth Planet. Inter, 41:215--224.

Dziewonski, A.M., Friedmann, A., Giardini, D., and Woodhouse, J.H., 1983b. Global seismicity of 1982: centroid-moment tensor solutions for 308 earthquakes. Phys. Earth Planet. Inter, 33:76-90.

Gable, R., Morin, R.H., and Becker, K., 1989. Geothermal state of Hole 504B: ODP Leg 111 overview. In Becker, K., Sakai, H., et al., Proc. ODP, Sci. Results, 111: College Station, TX (Ocean Drilling Program), 87-96.

Gebrande, H., 1982. Elasticity of rocks and minerals. In Angenheister, G., Cermak, V., Huckenholz, H.G., Rybach, L., Schmid, R., Schopper, J.R., Schuch, M., Stoeffler, D., and Wohlenberg, J. (Eds.), Physical Properties of Rocks: Berlin (Springer-Verlag).

Gough, D.I., and Bell, J.S., 1981. Stress orientations from oil-well fractures in Alberta and Texas. Can. J. Earth Sci., 18:638-645.

Handin, J., Hager, R.V., Jr., Friedman, M., and Feather, J.N., 1963. Experimental deformation of sedimentary rocks under confining pressure: pore pressure tests. AAPG Bull., 47:717-755.

Hüsges, S., and Müller, B., 1991. Televiewer-Untersuchung: Tiefbohrung Siblingen. Nagra Internal Rep.

Jaeger, J.C., and Cook, N.G.W., 1979. Fundamentals of Rock Mechanics (3rd ed.): New York (Chapman and Hall).

Kirsch, G., 1898. Die Theorie der Elastizität und die Bedürfnisse der Festigkeitslehre. VDI Z., 42:797-807.

Krammer, A., Menger, S., Chabernaud, T., and Fuchs, K., 1994. Borehole televiewer data analysis from the New Hebrides Island Arc: the state of stress at Holes 829A and 831B. In Greene, H.G., Collot, J.-Y., Stokking, L.B., et al., Proc. ODP, Sci. Results, 134: College Station, TX (Ocean Drilling Program).

Leinen, M., Rea, D.K., et al., 1986. Init. Repts. DSDP, 92: Washington (U.S. Govt. Printing Office).

Mardia, K.V., 1972. Probability and Mathematical Statistics: London (Academic Press)

Mastin, L.G., Heinemann, B., Krammer, A., Fuchs, K., and Zoback, M.D., 1991. Stress orientation in the KTB pilot hole determined from wellbore breakouts. Sci. Drill., 2:1-12.

Moos, D., and Zoback, M.D., 1990. Utilization of observations of well bore failure to constrain the orientation and magnitude of crustal stresses: application to continental, Deep Sea Drilling Project, and Ocean Drilling Program boreholes. J. Geophys. Res., 95:9305-9325.

Morin, R.H., Anderson, R.N., and Barton, C.A., 1989. Analysis and interpretation of the borehole televiewer log: information on the state of stress and the lithostratigraphy at Hole 504B. In Becker, K., Sakai, H., et al. Proc. ODP, Sci. Results, 111: College Station. TX (Ocean Drilling Program), 109-118.

Morin, R.H., Newmark, R.L., Barton, C.A., and Anderson, R.N., 1990. State of lithospheric stress and borehole stability at Deep Sea Drilling Project Site 504B, eastern Equatorial Pacific. J. Geophys. Res., 95:9293-9303.

Newmark, R.L. Zoback, M.D., and Anderson, R.N., 1985. Orientation of in situ stresses near the Costa Rica Rift and Peru-Chile Trench, Deep Sea Drilling Project Hole 504B. In Anderson, R.N., Honnorez, J., Becker, K., et al., Init. Repts. DSDP, 83: Washington (U.S. Govt. Printing Office), $511-514$.

Pezard, P.A., and Anderson, R.N., 1989. Morphology and alteration of the upper oceanic crust from in-situ electrical experiments in DSDP/ODP Hole 504B. In Becker, K., Sakai, H., et al., Proc. ODP. Sci. Results, 111 : College Station, TX (Ocean Drilling Program), 133-146.

Richardson, R.M., and Cox, B.L., 1984. Evolution of oceanic lithosphere: driving force study of the Nazca plate. J. Geophys. Res., 89:1004310052 .

Shamir, G., and Zoback, M.D., 1992. Stress orientation profile to $3.5 \mathrm{~km}$ depth near the San Andreas Fault at Cajon Pass, California. J. Geophys. Res., 97:5059-5080.

Skinner, B.J., 1966. Thermal expansion. In Clark, S.P., Jr. (Ed.), Handbook of Physical Constants. Mem.-Geol. Soc. Am., 97.

Stephansson, O., Ljunggren, C., and Jing, L., 1991. Stress measurements and tectonic implications for Fennoscandia. Tectonophysics, 189:317-322.

Stephen, R.A., 1985. Seismic anisotropy in the upper oceanic crust. J. Geophvs. Res., 90:11383-11396.

Stephens, G., and Voight, B., 1982. Hydraulic fracturing theory for conditions of thermal stress. Int. J. Rock Mech. Min. Sci., 19:279-284.

Tenzer, H., Mastin, L.G., and Heinemann, B., 1992. Determination of planar discontinuities and borehole geometry in the crystalline rock of Borehole GPK-1 at Soultz sous Forets. In Bresee, J.C. (Ed.), Geothermal Energy in Europe: The Soultz Hot Dry Rock Project: Philadelphia (Gordon \& Breach), 31-67.

Timoshenko, S., and Goodier, J.N., 1970. Theory of Elasticity: New York (McGraw-Hill).

Wortel, M.J.R., and Cloetingh, S.A.P.L., 1985. Accretion and lateral variations in tectonic structure along the Peru-Chile trench. Tectonophysics, 112:443-462.

Zemanek, J., Glenn, E.E., Norton, L.J., and Caldwell, R.L., 1970. Formation evaluation by inspection with the borehole televiewer. Geophysics, $35: 254-269$.

Zoback, M.D., and Anderson, R.N., 1983. Permeability, underpressures, and convection in the oceanic crust at Deep Sea Drilling Project Hole 504B In Cann, J.R., Langseth, M.G., Honnorez, J., Von Herzen, R.P., White, S.M., et al., Init. Repts. DSDP, 69: Washington (U.S. Govt. Printing Office), 245-254.

Zoback, M.D., Moos, D., Mastin, L., and Anderson, R.N., 1985. Well bore breakouts and in situ stress. J. Geophys. Res., 90:5523-5530.

Date of initial receipt: 14 May 1993

Date of acceptance: 15 December 1993

Ms 137/140SR-034 